\title{
Floodplain Analysis using ArcGIS, HEC-GeoRAS and HEC-RAS in Attarat Um Al-Ghudran Oil Shale Concession Area, Jordan
}

\author{
Ali El-Naqa and Mohammad Jaber* \\ Department of Water Management and Environment, Faculty of Natural Resources and Environment, Hashemite University, Zarqa, Jordan
}

\begin{abstract}
Flood is a natural disaster and causes loss of life and property destruction. The objective of this study was to analyze flood inundation area mapping at Wadi Attarat Um Al Ghurdan Oil Shale mining concession area, The flooded areas along the main Wadi of Al-Ghadaf catchment area have been mapped based on the flow rates for different return periods using the HEC-RAS model, GIS for spatial data processing and HEC-GeoRAS for interfacing between HECRAS and GIS. The areas along the main wadi in the study area were simulated to be inundated for $5,10,25,50$ and 100 years return periods. An inundation map displays the spatial extent of probable flooding for different scenarios and can be present either in quantitative or qualitative ways. The flood inundation maps for 25, 50 and 100 years return periods were prepared using ArcGIS. The major findings in the study revealed that the water level in some localities in the inundated areas reaches approximately $5.0 \mathrm{~m}$ along the wadi. Therefore, proper flood management can be adopted to reduce the adverse effects of flooding particularly in the low-lying flood prone areas.
\end{abstract}

Keywords: Flood; Inundation; HEC-RAS; HEC-GeoRAS; Oil Shale; ASTER GDEM, Jordan

\section{Introduction}

Floods are costly natural disasters causing fatalities, damages to life, property, communications, transportation, and critical infrastructures [1]. Flood is defined as a water flow with high discharge, which water rises and drowning out its land around that are not usually under water [2]. Annually, nearly 99 million people worldwide were affected by floods during the period 2000-2008 [3]. Floods can happen anywhere with its effects are clearer in developing countries due to their low incomes, poor housing facilities, inadequate warning systems and preparedness [4]. In addition to that, climate change will have a key role in changing the hydrological cycle through affecting precipitation, surface runoff, soil moisture, and the recharge rates of ground water [5] and by intensifying and accelerating it, which may increase the magnitude and frequency of future floods [6]. Flood inundation maps are dependent on the topographic and geomorphologic features of a wadi (drainage basin) in arid regions, which are most susceptible for potential flash flood occurrences [7].

By using geographic information system (GIS) software and remote sensing technique flash flood hazard maps can be generated which are an important tool for municipal, urban growth planning and emergency action plans [8].

Floodplain modeling is a relatively new and applied method in river engineering discipline and is essential for prediction of flood hazards, and the purpose of managing and performing all river training practices [9]. For this Study, integrating of HEC-RAS [10] and ArcGIS were used to prepare inundation map (inundation extents and depths) within the Attarat Oil Shale concession area for floods of different return periods. The Hydrologic Engineering Center River Analysis System (HEC-RAS) model was developed by the U.S. Army Corps of Engineers [11]. This research has not only provided useful hydraulic analysis in an ungauged major wadi, but also suggested an improvement of flood risk and mapping practices. The knowledge generated by this research can be transferred to other study areas with similar climatic conditions in the world [12]. The lack of data for ungauged rivers often deprives researchers to have an accurate prediction of flood magnitude as a key factor for a reliable flood inundation mapping [13]. This study is attempted to derive design flood profiles and flood inundation maps in the oil shale mining area as the precaution for flood management plan. The objective of this project was to develop floodplain maps for a concession area of Attarat Um Al-Ghudran Oil Shale area, Central Jordan [14]. The study was performed using the functionality of ArcGIS to improve the floodplain results obtained using only the Hydrologic Engineering Center's River Analysis System (HEC-RAS) [10]. This will be done by mapping the extents of the floodplain along the major wadi in the study area at different flood flow rates. Three floodplains were mapped associated with flow rates of 9,19 and $25 \mathrm{~m}^{3} / \mathrm{s}$. The software used in this study for floodplain mapping was ESRI's ArcMap and the HECGeoRAS extension [15]. The US Army Corps of Engineers (USACE) has developed a GIS extension for ArcMap called HEC-GeoRAS [15], which was used to prepare the geospatial information for the hydraulic model and process the results. The hydraulic models were calculated using the USACE river analysis software (HEC-RAS 5.0). Ultimately, the analysis was used to create maps with ArcMap that visually show the reach of the floodplains, illustrating the potential areas affected.

\section{Description of the study area}

The study area is located in the central part of Jordan (Figure 1) and belongs to Azraq surface water basin. The MOU area is about $11 \mathrm{~km}^{2}$ and located in Wadi Attarat Um Ghudran map sheet area. It is about $110 \mathrm{~km}$ from Amman via the Amman-Aqaba highway. The area lies between the coordinates 289000 to 293000 PGE and 1082000 to 1085000 PGN with the total area of about $11 \mathrm{~km}^{2}$. The study area is located within Wadi Al-Ghadaf catchment area which covers approximately $359 \mathrm{~km}^{2}$. The average annual rainfall of Wadi Al-Ghadaf catchment area is about $58 \mathrm{~mm}$.

\section{Methodology}

The general method for creating floodplain maps for a river has three major stages: Preprocessing, processing, and post processing of the data. These stages will be described in depth in subsequent sections.

${ }^{*}$ Corresponding author: Mohammad Jaber, Faculty of Natural Resources and Environment, Department of Water Management and Environment, Hashemite University, Zarqa, Jordan, Tel: +962775230138; E-mail: mohammadm_mo@hu.edu.jo

Received July 20, 2018; Accepted October 01, 2018; Published October 05, 2018

Citation: El-Naqa A, Jaber M (2018) Floodplain Analysis using ArcGIS, HECGeoRAS and HEC-RAS in Attarat Um Al-Ghudran Oil Shale Concession Area, Jordan. J Civil Environ Eng 8: 323. doi: 10.4172/2165-784X.1000323

Copyright: $\odot 2018$ El-Naqa A, et al. This is an open-access article distributed under the terms of the Creative Commons Attribution License, which permits unrestricted use, distribution, and reproduction in any medium, provided the original author and source are credited. 
Figure 2 illustrates the three stages for floodplain mapping used in this study along with the main tasks accomplished within those stages. This methodology is applicable to floodplain mapping for any river system.

The floodplain mapping for this study was done with ArcGIS, HECGeoRAS, and HEC-RAS. The Preprocessing stage consisted mostly of model input data preparation and was done in ArcGIS using the HECGeoRAS extension. The processing stage was done completely within HEC-RAS using the river geometry prepared in the previous stage. The final stage consists of analyzing the results from the HEC-RAS model within ArcMap. HEC-GeoRAS helps in creation of the data needed for the HEC-RAS model and the transfer of data between ArcGIS and HEC-RAS

\section{Pre-processing}

The first stage in determining floodplains for the study area was preprocessing. This study aims to create a simplified Steady flow hydrologic model of the Wadi Al-Ghadaf reach within the concession area of Attart Al-Ghudran Oil Shale to compute flood inundation. The model is built and run using the Hydrologic Engineering Centers

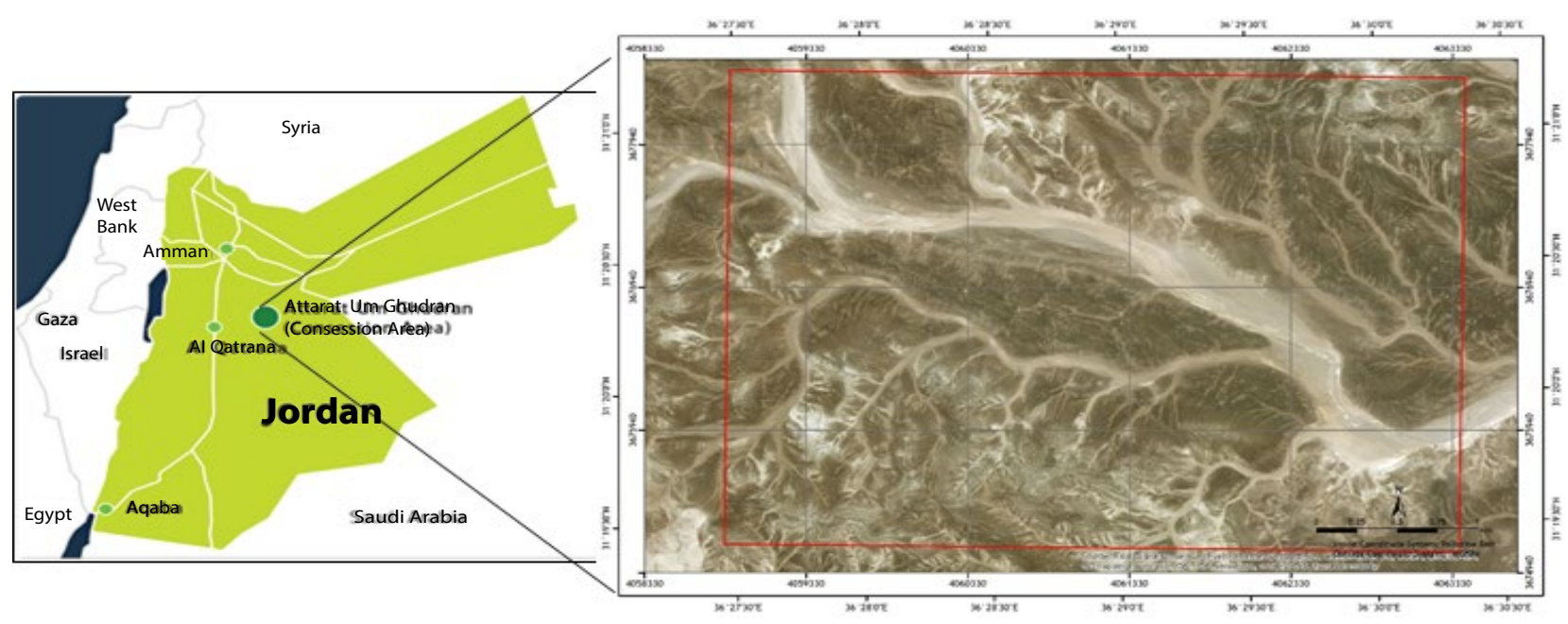

Figure 1: Location map of Attarat Um Al-Ghudran Oil shale concession area.

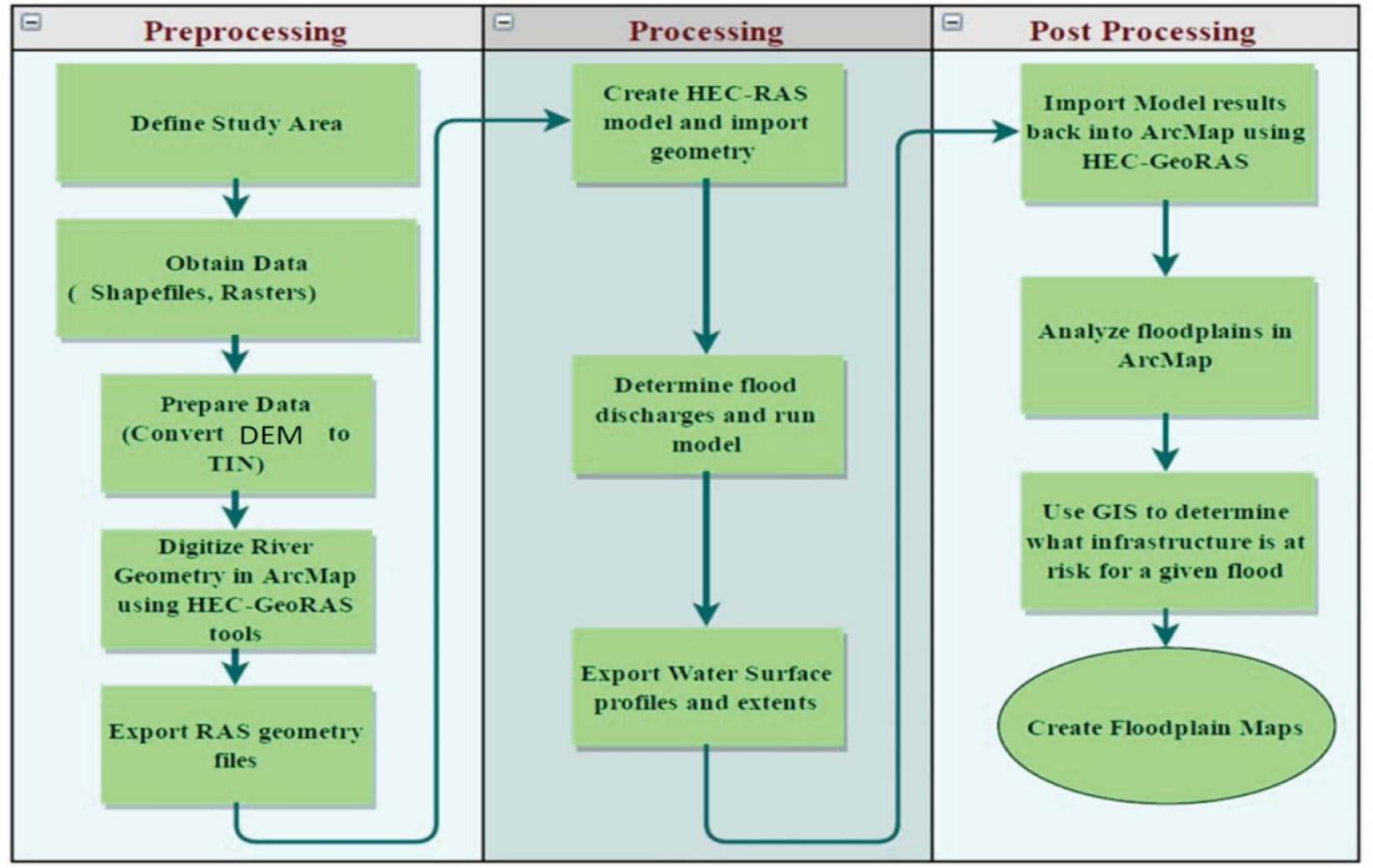

Figure 2: General method for modeling floodplains using ArcGIS, HEC-GeoRAS and HEC-RAS. 
River Analysis System (HEC-RAS 5.1.0), a river modeling software developed by the USACE. HEC-RAS is a free computer program which enables users to perform a variety of hydrologic simulations including streamflow analyses. HEC-RAS is widely used in management operations as well as research, and is accepted as an efficient program for developing flood models and inundation maps [16].

To construct the model of the Attarat Oil shale concession area in HEC-RAS, three specific input parameters must be specified: Stream Geometry, Flow Data, and the Model Plan [17].

The preprocessing stage consisted mostly of collecting and preparing data for the hydraulic model. To begin, a section of the major Wadi River was defined in the study area. Once the study area was defined, the features that might be affected in the event of flooding can be deduced. In order to create the necessary wadi river geometry for HEC-RAS, elevation data were needed. High resolution digital elevation model data was obtained from Advanced Spaceborne Thermal Emission and Reflection Radiometer (ASTER) $30 \mathrm{~m}$ resolution.

The elevation data were converted to a triangulated irregular network (TIN) elevation model, then the next step was to create the river geometry in ArcGIS (Figure 3). The HEC-GeoRAS extension was used to set up the necessary features that would be needed for the HEC-RAS model (i.e., stream centerline, bank lines, cross sections, etc.). HECRAS uses these features to obtain an accurate layout of the river and to establish the cross-sectional elevations of the potential floodplains. The cross sections must extend far enough to ensure that all water from the flood is contained within the cross-sectional area. Methods for setting up the model using HEC-GeoRAS were taken from the HEC-GeoRAS user manual [15]. The river geometry was digitized using the ArcGIS editing features. Figure 3 shows the digitized river features on top of the TIN.

HEC-GeoRAS uses the line features in conjunction with the TIN to extract elevations for the cross sections and flow profile. In addition to elevations, Manning's roughness coefficient values were applied to the cross sections using land cover data obtained from Ministry of Agriculture.

The Manning's roughness values represent the roughness of the channel surface, which can influence the overall flow rates and velocities in the channel. The land cover data for the study area were downloaded and converted from a raster to a polygon shapefile. A value of Manning's roughness was assigned to each land cover category.

\section{Processing}

The geometry data created in ArcMap were exported into HECRAS. Once in HEC-RAS, it was necessary to modify and correct the designated left and right banks of the river. The left and right banks defined in ArcMap using the HEC-GeoRAS extension didn't match the actual left and right banks. The solution to this problem was to use the cross section editor in HECRAS and manually select the left and right banks based off of the cross section geometry.

After correcting the geometry, a steady flow analysis was used to route three flows of 9,19 and $25 \mathrm{~m}^{3} / \mathrm{s}$ through the river. The steady flow analysis produced water surface profiles and the extents of each floodplain.

HEC-RAS uses a number of input parameters for hydraulic analysis of the stream channel geometry and water flow. These parameters are used to establish a series of cross-sections along the stream as shown in Figure 4. In each cross-section, the locations of the stream banks are identified and used to divide into segments of left floodway, main channel, and right floodway (Figures 5 and 6). HEC-RAS subdivides the cross sections in this manner, because of differences in hydraulic parameters. For example, the wetted perimeter in the floodway is much higher than in the main channel. Thus, friction forces between the water and channel bed have a greater influence in flow resistance in the floodway, leading to lower values of the Manning coefficient. As a result, the flow velocity and conveyance are substantially higher in the main channel than in the floodway.

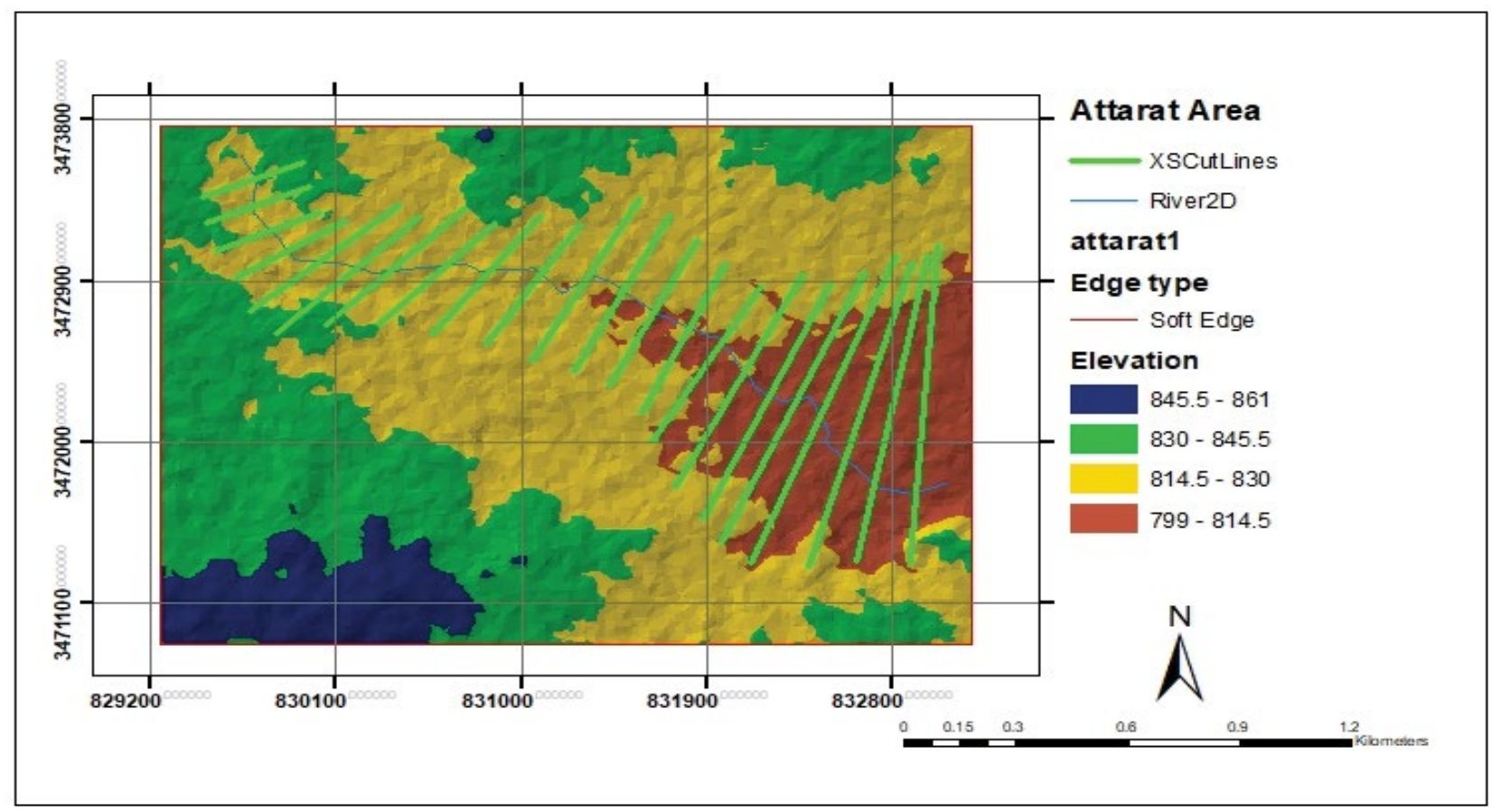

Figure 3: River wadi geometry created in ArcGIS overlaying the TIN. 
Citation: El-Naqa A, Jaber M (2018) Floodplain Analysis using ArcGIS, HEC-GeoRAS and HEC-RAS in Attarat Um Al-Ghudran Oil Shale Concession Area, Jordan. J Civil Environ Eng 8: 323. doi: 10.4172/2165-784X.1000323

Page 4 of 11

At each cross-section, HEC-RAS uses several input parameters to describe shape, elevation, and relative location along the stream (Figure 5):

- River station (cross-section) number.

- Lateral and elevation coordinates for each (dry, unflooded) terrain point.

- Left and right bank station locations.

- Reach lengths between the left floodway, stream centerline, and right floodway of adjacent cross-sections (The three reach lengths represent the average flow path through each segment of the cross-section pair. As such, the three reach lengths between adjacent cross-sections may differ in magnitude due to bends in the stream).

- Manning's roughness coefficients.

- Channel contraction and expansion coefficients.

- Geometric description of any hydraulic structures, such as bridges, culverts, and weirs.

\section{Post processing}

For each cross section worksheet the following data were enetered.

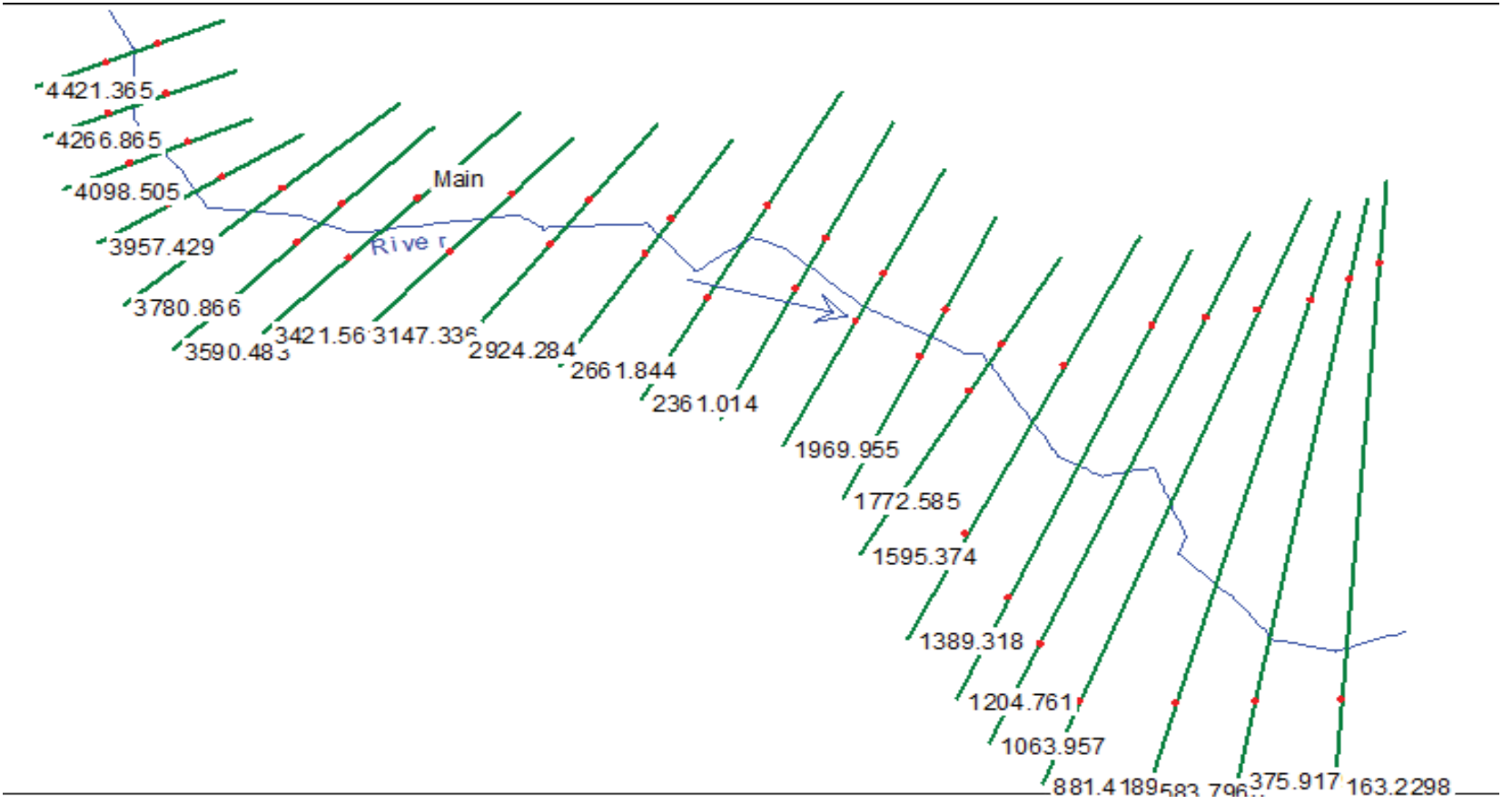

Figure 4: Location of the selected cross sections along the main reach (Wadi Attarat).

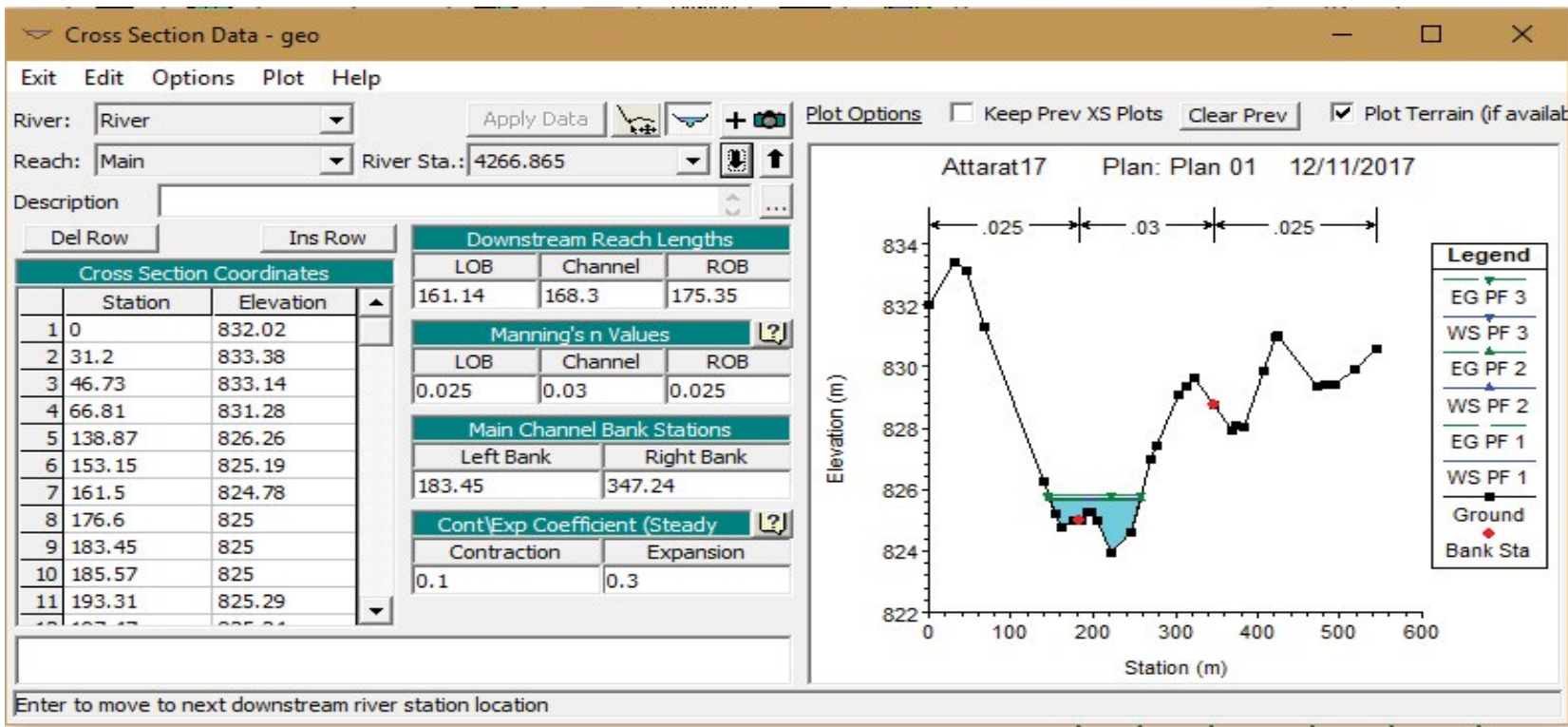

Figure 5: HEC-RAS cross-section input parameters. 
Citation: El-Naqa A, Jaber M (2018) Floodplain Analysis using ArcGIS, HEC-GeoRAS and HEC-RAS in Attarat Um AI-Ghudran Oil Shale Concession Area, Jordan. J Civil Environ Eng 8: 323. doi: 10.4172/2165-784X.1000323

Page 5 of 11

The steady Flow tab comprises an input section on the left and an output, or results, section on the right. Figure 6 shows an example of the output of the flood for different return period.

The water surface profile for a flood of 25, 50 and 100 years return period in the project area as a result of steady flow analysis in HECRAS is shown in Figures 7, 8 and 9.

The results from the HEC-RAS model were then imported back into ArcMap using the HEC-GeoRAS tool. After importing the results into ArcMap it was clear it was necessary to correct errors in the extents of the flood plains. The error seen in the HEC-RAS model results was flooding being shown in ineffective flow areas. Ineffective flow areas are areas of low elevation that do not connect with the main floodplain area. If not defined, HEC-RAS will route water through these areas in the simulation. The solution to this problem was to use the cut tool in ArcMap, and remove the erroneous results.

Determination of peak flow rates for floods: The Unit hydrograph approach is used in this study to determine the peak flow rate or peak discharge and its magnitude values. The results obtained by applying these applications are acceptable for hydrological simulation purposes. The synthetic unit hydrograph and USA Soil Conservation Service (SCS) methods were being selected, which can be applicable to catchments between 5 and $5000 \mathrm{~km}^{2}$. The SCS dimensionless unit hydrograph has been used in determining of the hydrograph shape and flood volume and the initial abstraction is being estimated using the SCS Curve Number $(\mathrm{CN})$ method. The peak floods are computed for flood return period of 5, 10, 25, 50, 100, and 200 years.

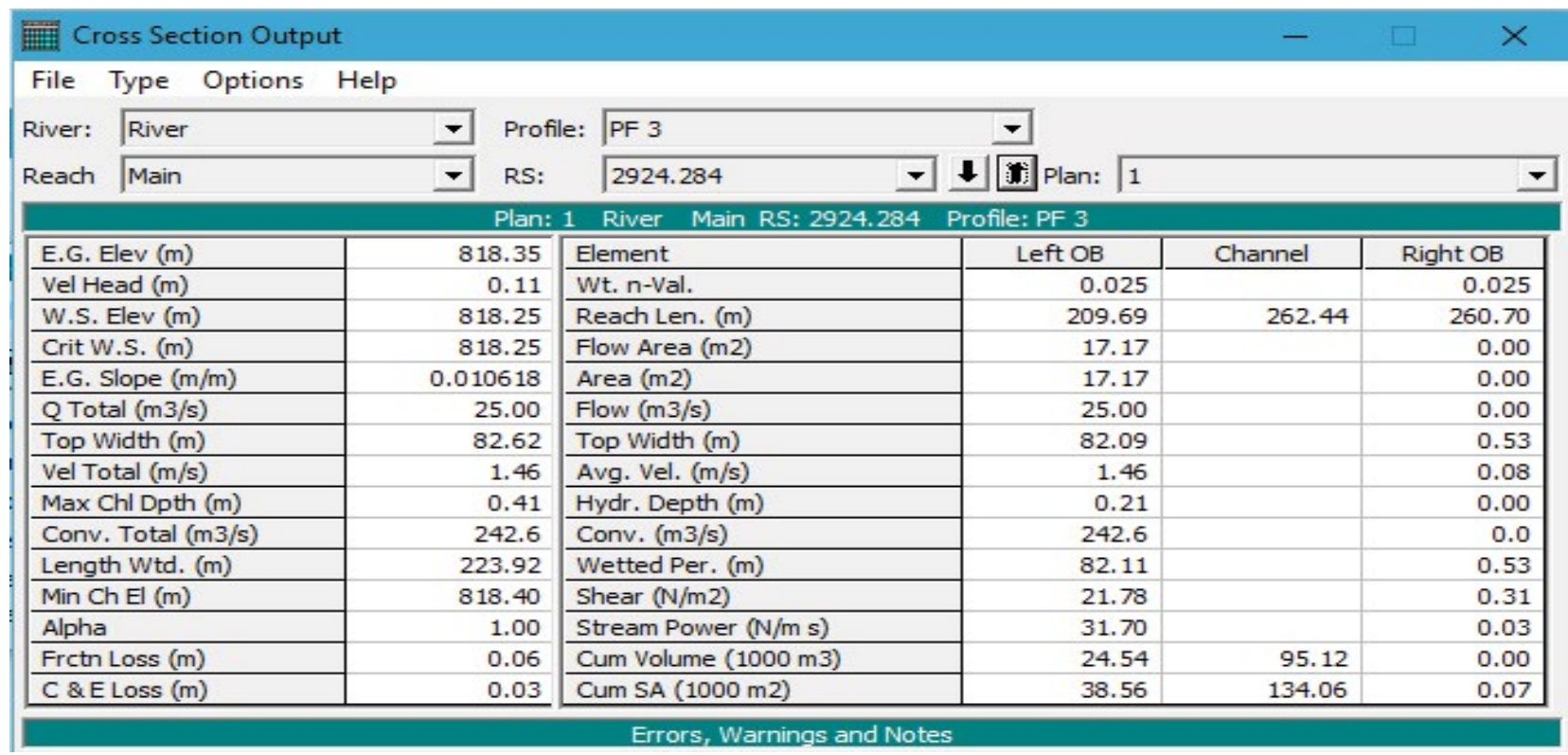

Figure 6: Output of hydraulic analysis of cross section.

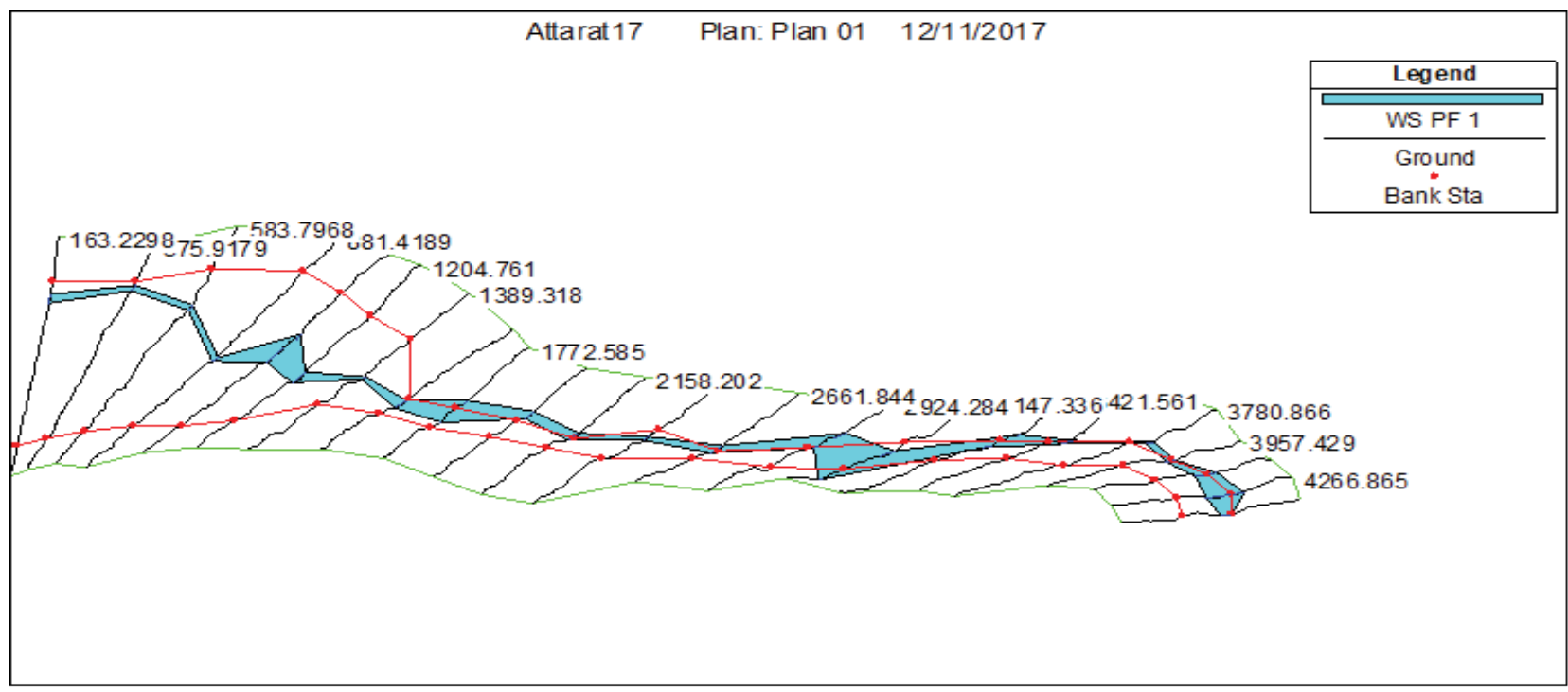

Figure 7: 3-D view of water surface profile for a flood of 25 years return period. 
A hydrological model was constructed to determine the runoff in the main tributaries of main wadi in the project area. The first step in constructing a hydrological model is to generate the Digital Elevation Model $(30 \mathrm{~m} \times 30 \mathrm{~m})$ with the aid of ArcGIS. The cells are treated as Geo-unit where water could accumulate when drainage patterns are being extracted.

The ordinates of the dimensionless hydrograph are given in literature and the ordinates will be multiplied by qp and tp to give the UH for the catchment concerned. Since these values will not generally be for convenient intervals of $1 / 4,1 / 2,1$ or 2 hours, the values are interpolated. The overall volume of runoff indicated by this adjusted $\mathrm{UH}$ is calculated and the $\mathrm{UH}$ ordinates are then factored in order to achieve the exact unit runoff required. Dimensionless ratios of $Q / Q p$ on the ordinate and $\mathrm{T} / \mathrm{Tp}$ on the abscissa where $\mathrm{Qp}$ and Tp are the peak flow and time to peak, respectively, are used to specify the hydrograph.

According to the hydrological parameters of the watersheds, the average estimated value of the peak discharge at the outlet of the project area catchment ranges is approximately $43 \mathrm{~m}^{3} / \mathrm{s}$ using the curve number 90 (Figure 10). The UH is multiplied by the effective rainfall out of the design storms at different return periods in order to produce the runoff hydrographs. The peak floods of the hydrographs of 2 year, 5 year, 10 year, 25 year, 50 year, 100 years and 200-year return periods have been extracted as shown in the Figures 11, 12 and 13 respectively.

Runoff frequency analysis: In this section an attempt to evaluate the frequency and magnitude of the flood flow at the selected sites. The approach that used the daily series of the runoff magnitude occurred in each water year is very common approach in hydrological studies. This approach is used to compute runoff results which have been obtained from the calculations of the recorded data of daily rainfall for the available water year when the runoff record is not available or not have long enough data for the statistical analysis.

To evaluate the frequency and magnitude of the daily runoff volume series (computed from daily rainfall) and its risk of flooding. The daily rainfall events used to calculate the flood return period was chosen from the historical data for the period of 1960/1961 up to 2015/2016.

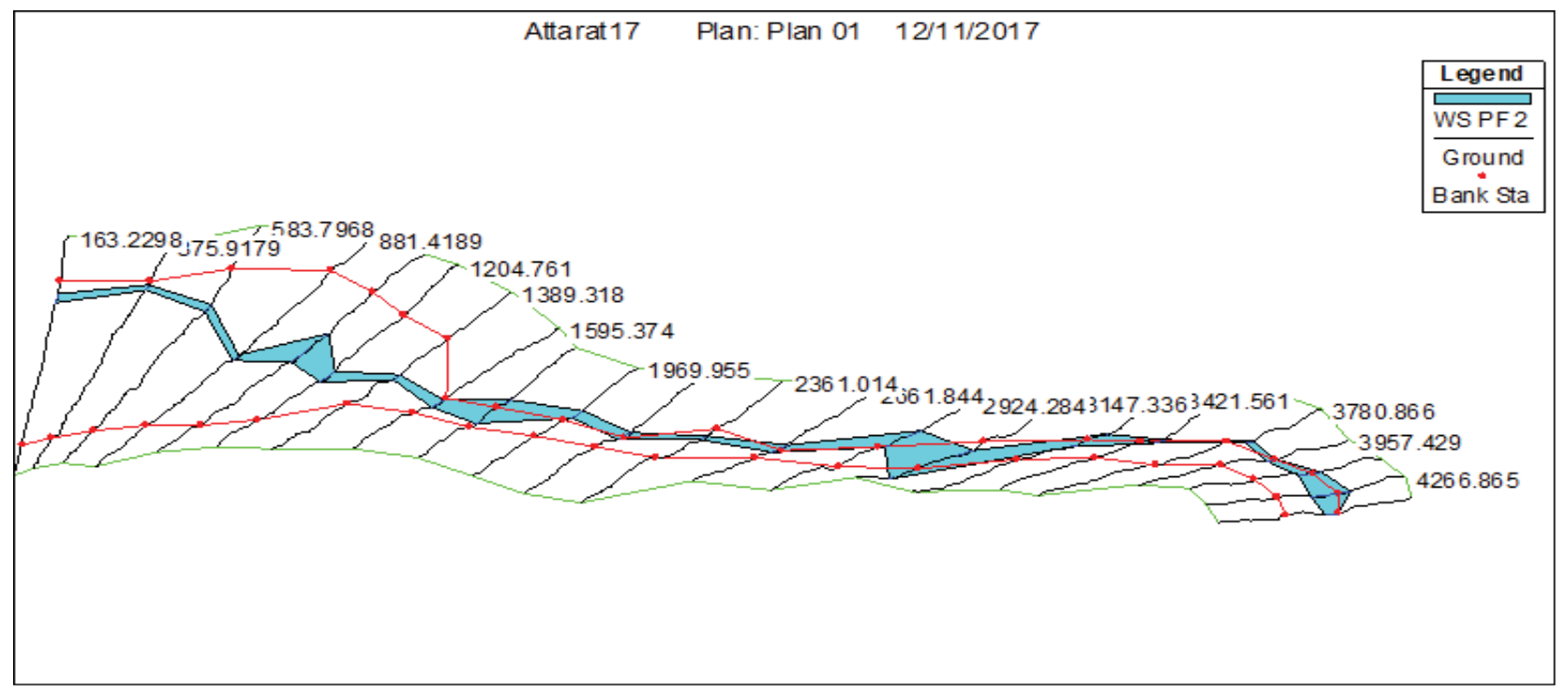

Figure 8: 3-D view of water surface profile for a flood of 50 years return period

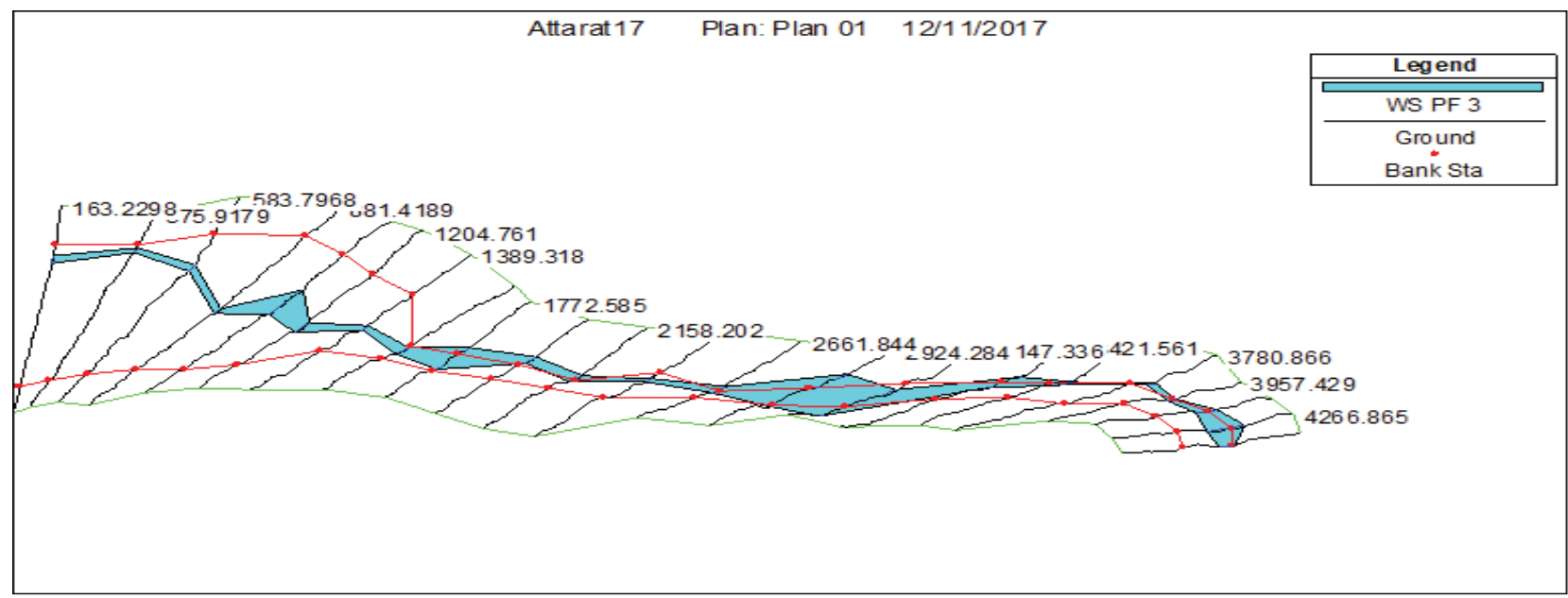

Figure 9: 3-D view of water surface profile for a flood of 100 years return period. 


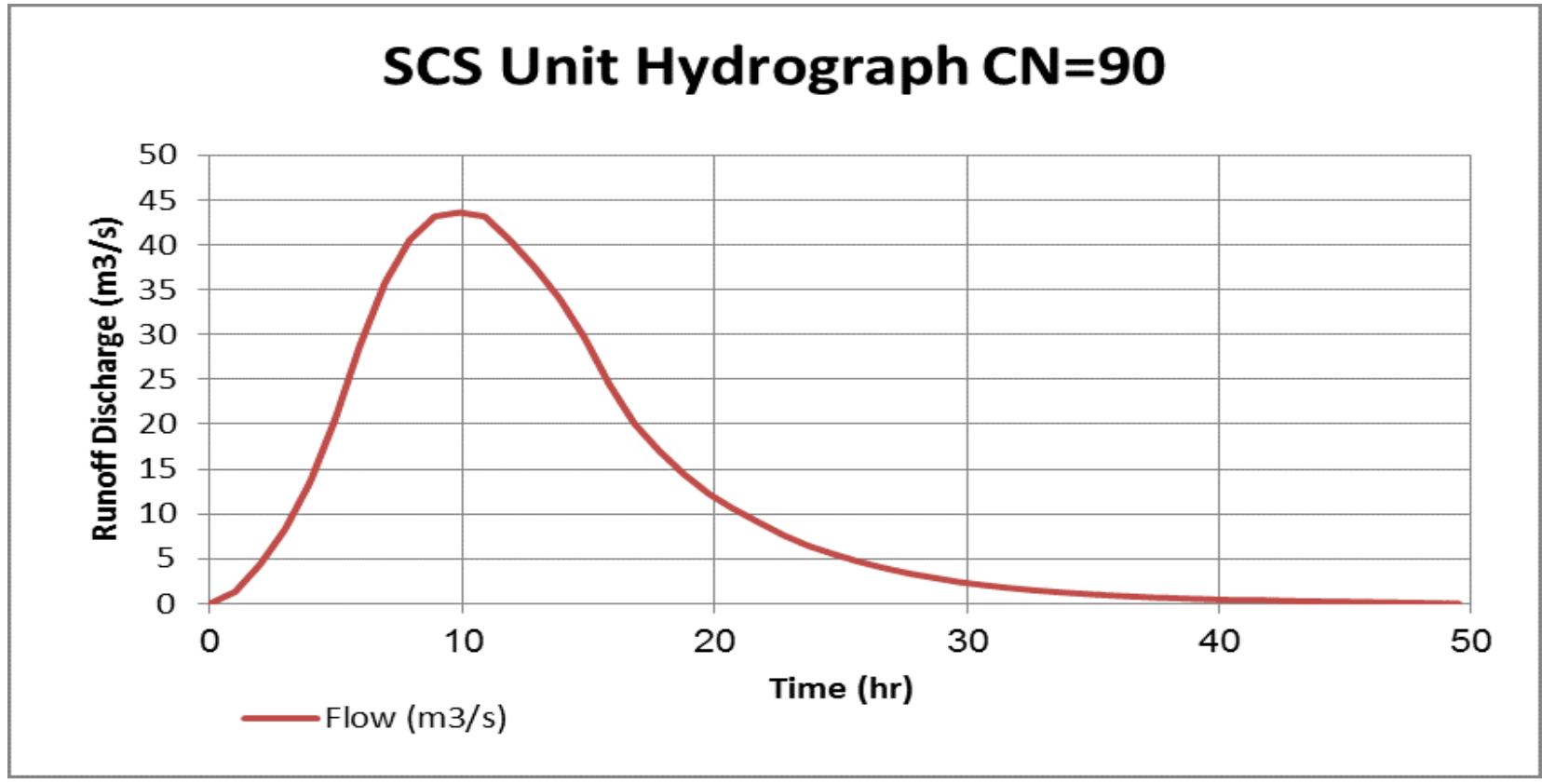

Figure 10: SCS synthetic unit hydrograph for project area.

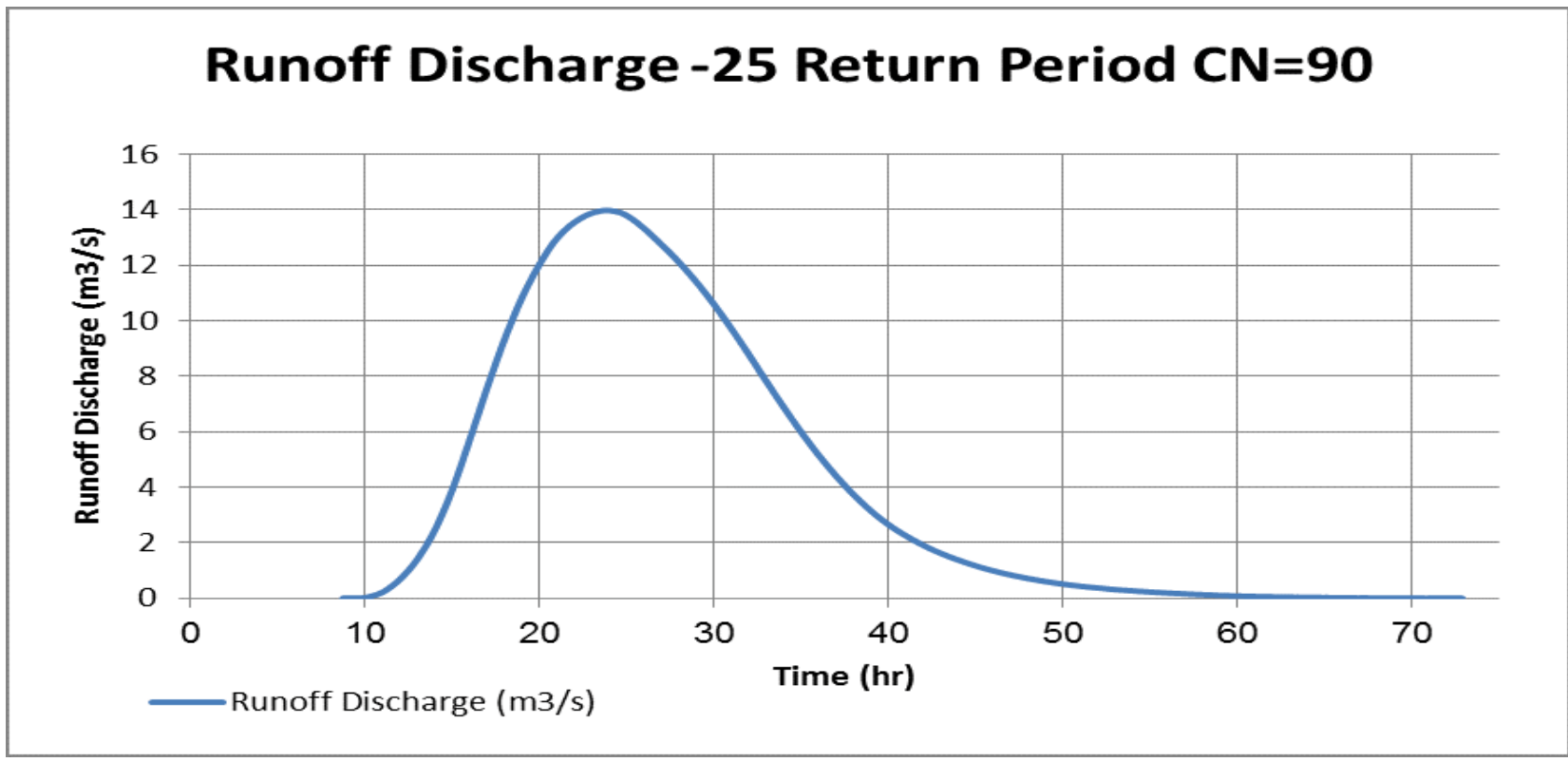

Figure 11: Runoff discharge hydrograph for 25-year return period.

\section{Results and Discussion}

\section{Flood inundation maps using HEC-GeoRAS}

Flood Inundation Mapping is an important tool for engineers, planners, and government agencies used for understanding the extent of flooding and floodwater inundation, to best allocate resources to prepare for emergencies and to generally improve the quality of life. The Hydrologic Engineering Center's River Analysis System (HECRAS) is a software package that is well-suited for developing flood inundation maps for a variety of applications.
The purpose of this study was to produce floodplain maps for the major river wadi in the study area at various flow rates. Three flow rates were analyzed, and the resulting floodplains were mapped using ArcMap. In order to more accurately analyze the floodplains and affected areas, the floodplain areas were mapped with specific shapefile features within the study area.

Figure 7 shows a land that was affected by the highest modeled flow rate. It can be seen that there are many land parcels that would be inundated with water during a flood event of this magnitude.

Once the HEC-RAS model was complete, output data was exported 


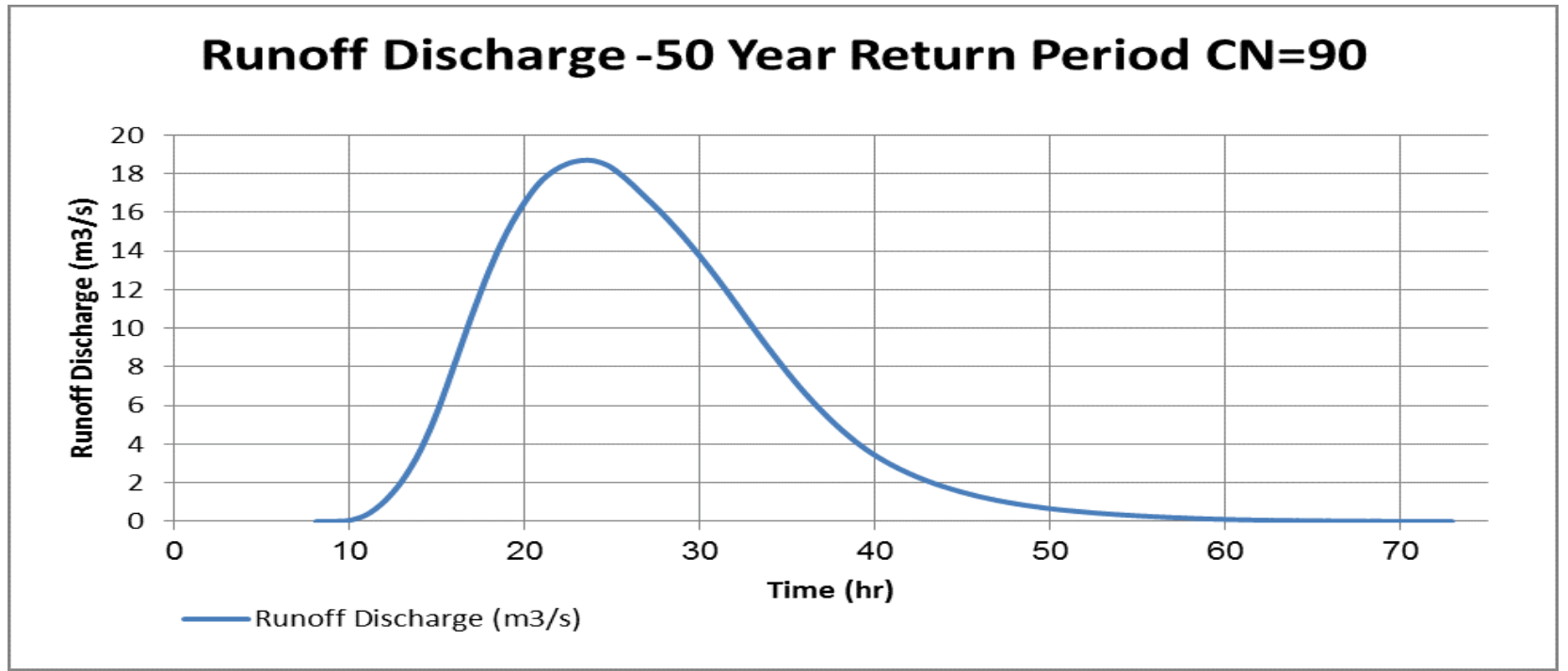

Figure 12: Runoff discharge hydrograph for 50-year return period.

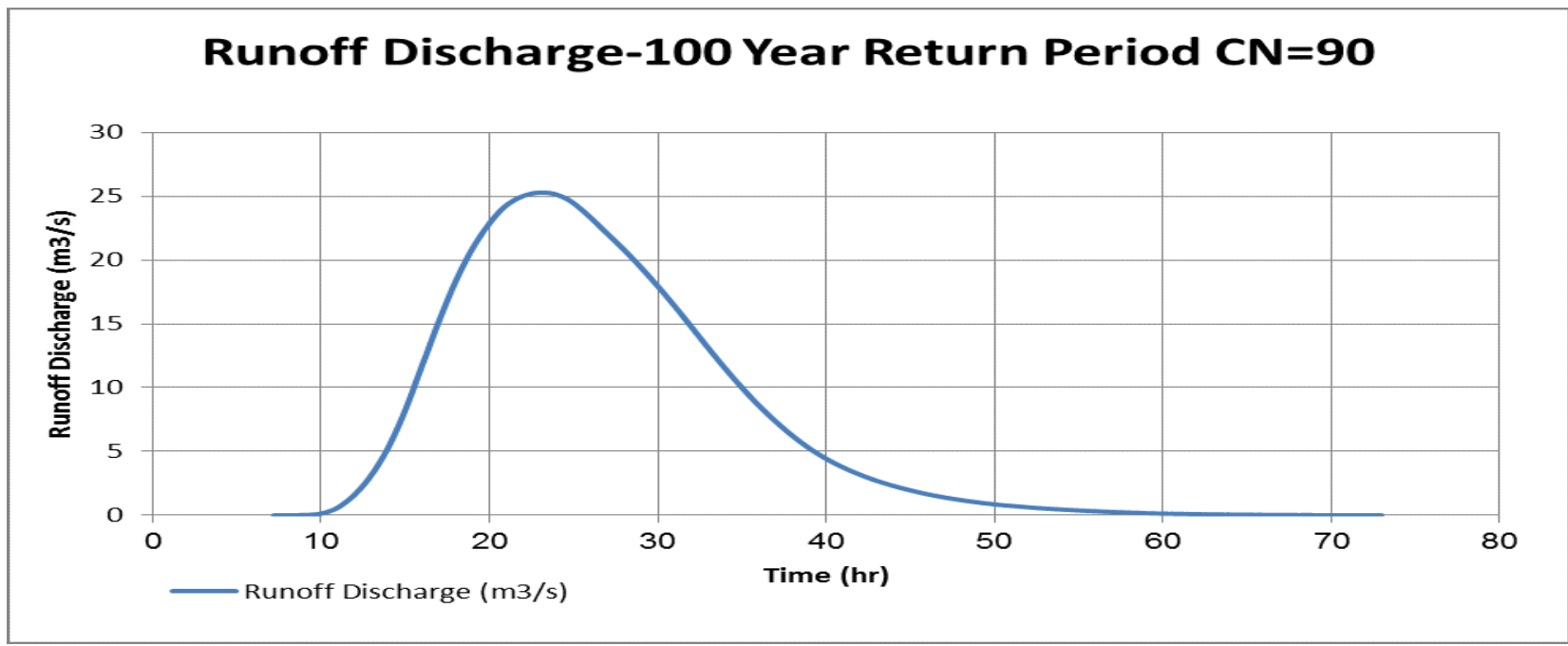

Figure 13: Runoff discharge hydrograph for 100-year return period.

to GIS. HEC-GeoRAS was used to compile the data into useful graphical output such as floodplain polygon shape files. To generate floodplain shape files, the GeoRAS extension is used to first create a water surface TIN for each of the flood events. The water surface TIN is automatically clipped to fall within the bounds of the cross sections (i.e., it does not extend beyond the end points of any cross section), and is completely independent of the terrain TIN. After the water surface TIN is created, the rasterization of the water surface TIN and the terrain TIN takes place and the floodplain is delineated where the water surface exceeds the terrain elevations.

HEC-RAS and its companion GIS extension HEC-GeoRAS can aid in the development of flood inundation maps. HECRAS is a powerful, yet easy-to-use software package for determining water surface profiles in a wide variety of streams. GeoRAS can post-process the HEC-RAS data into polygon shape files that define the extents of flooding for a given flood. The results presented in the form of ArcView ${ }^{\odot}$ shape file polygons and lines were generated in the steady flow version of HECRAS, which is a one-dimensional model. The flood inundation maps created by HEC-RAS for 25, 50 and 100-year flood events in the project area are shown in Figures 14, 15 and 16 respectively.

\section{HEC-RAS sensitivity analysis}

The sensitivity of the HEC-RAS model to variations in Manning's (n) and to variations in streambed elevation was evaluated. The procedure involves holding all input parameter constant except the one being analyzed and then varying that value. Changes in modelsimulated water-surface elevations were used to determine the sensitivity of the model to changes in Manning's $n$ and to changes in stream bed elevation. For all sensitivity simulations, the boundary conditions at the upstream and downstream cross sections were not changed. All sensitivity analyses were conducted for peak flow of 28 $\mathrm{m}^{3} / \mathrm{s}$ with return period of 100 years and average channel slope of 0.009. Water surface elevation changes, however, at these high peak flows probably are more dependent on the magnitude of the flow than on the channel roughness indicated by Manning's (n). 
To determine the sensitivity of the model to variations in Manning's (n), a series of simulations for the peak flow of $28 \mathrm{~m}^{3} / \mathrm{s}$ were made in which the $n$ value was varied by $\pm 20 \%$ on baseline conditions. For these analyses Manning's $n$ was adjusted and the range of analysis was $\pm 20 \%$ from the baseline estimated value 0.025 .

The sensitivity analyses were performed for the 100-year estimated peak discharge of $28 \mathrm{~m}^{3} / \mathrm{s}$ and are reported in terms of the response variables as well as water surface elevation. The results are summarized in Table 1 . The results from the Manning's $\mathrm{n}$ sensitivity analyses for both response variables demonstrated anticipated directional changes where the rate of change among the response variable ranged from approximate $\pm 4-16 \%$. The rate of change as the Manning's roughness coefficient increases from 0.02 to 0.03 the average velocity and average Froude number decreased by $-12.9 \%$ (i.e., from $3.73 \mathrm{~m} / \mathrm{s}$ to $2.88 \mathrm{~m} / \mathrm{s}$ ) and $-17.8 \%$ (i.e., from 1.45 to 1.01 ) respectively while the average hydraulic

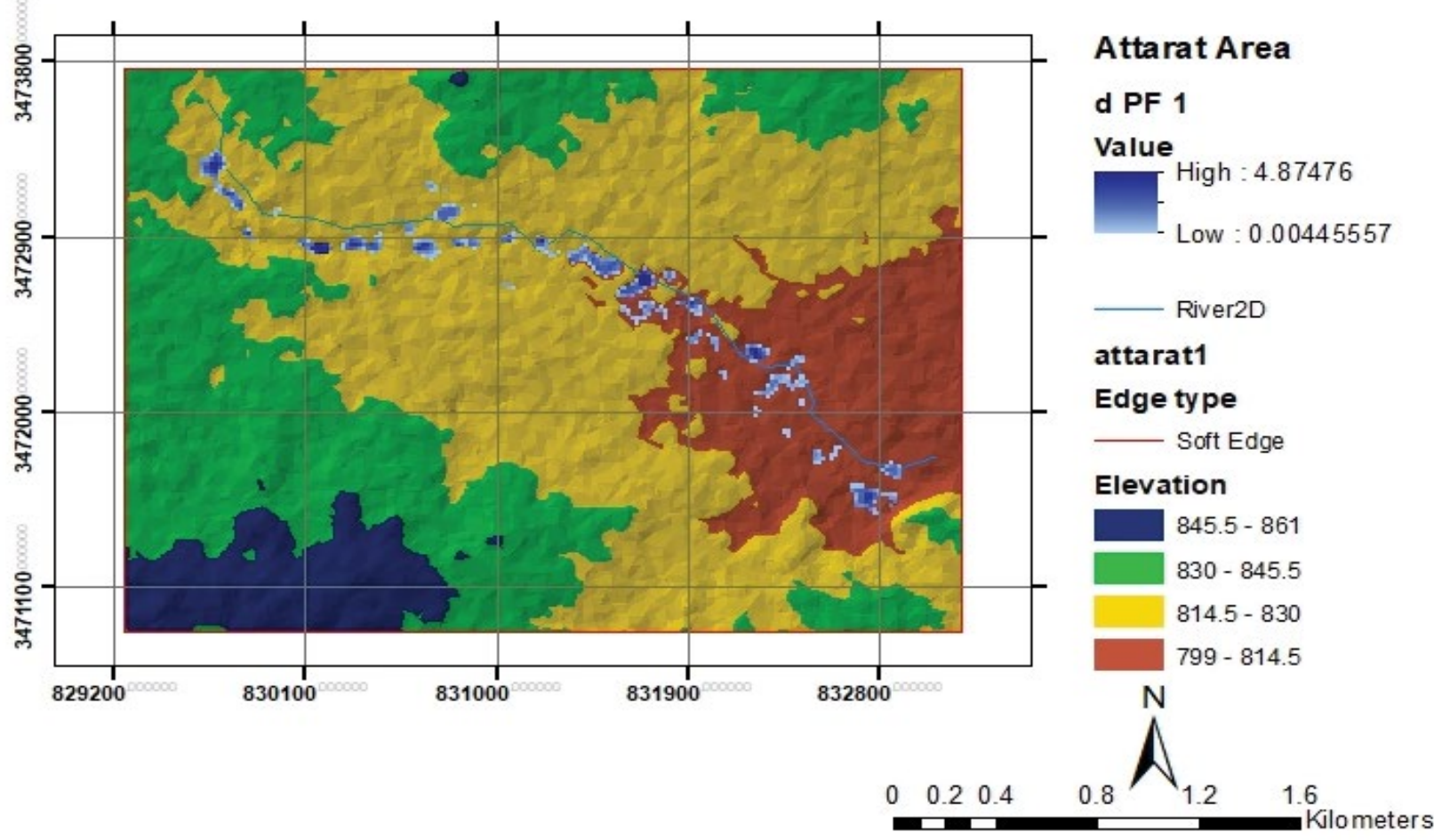

Figure 14: Floodplains for 25 years flow rate on the project area.

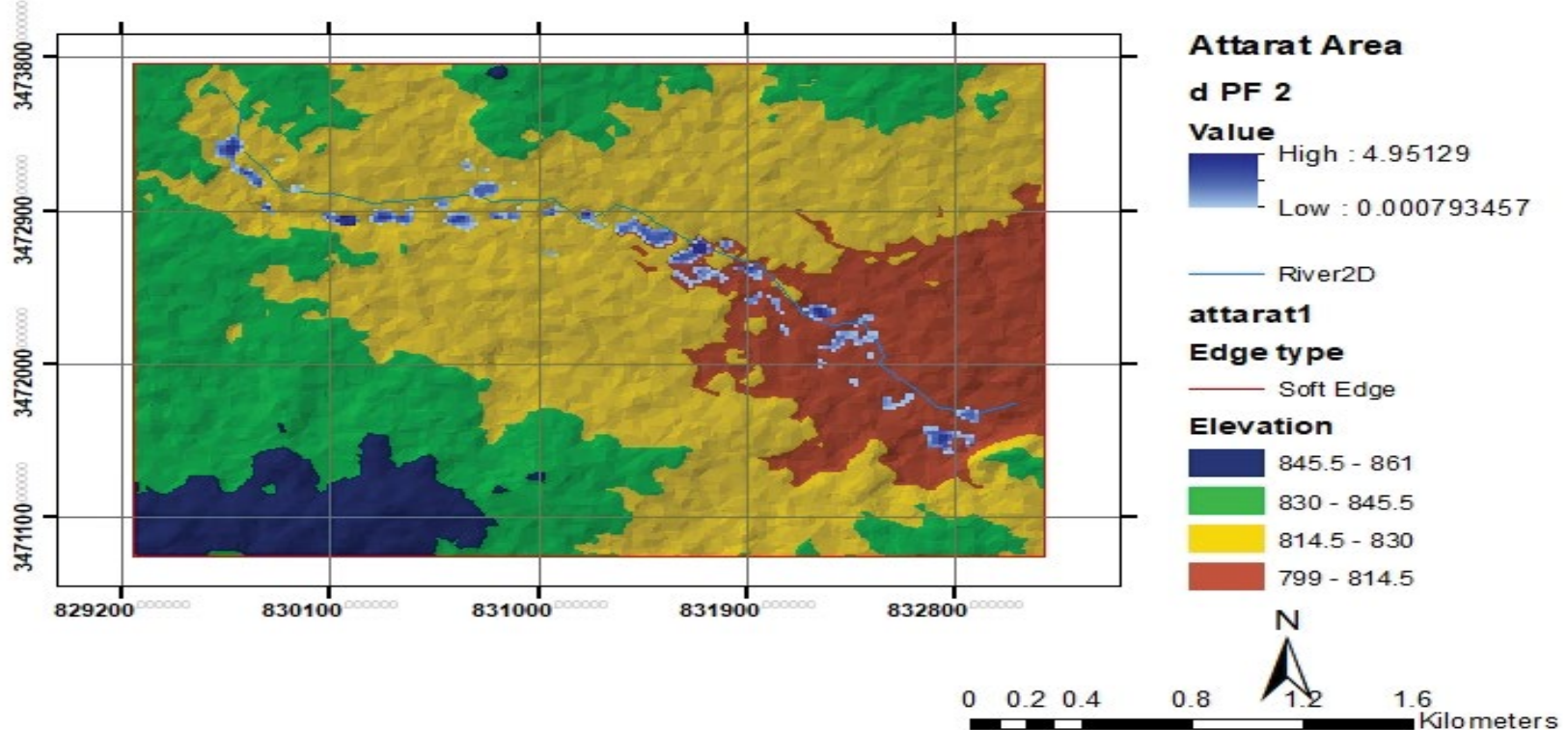

Figure 15: Floodplains for 50 years flow rate on the project area. 


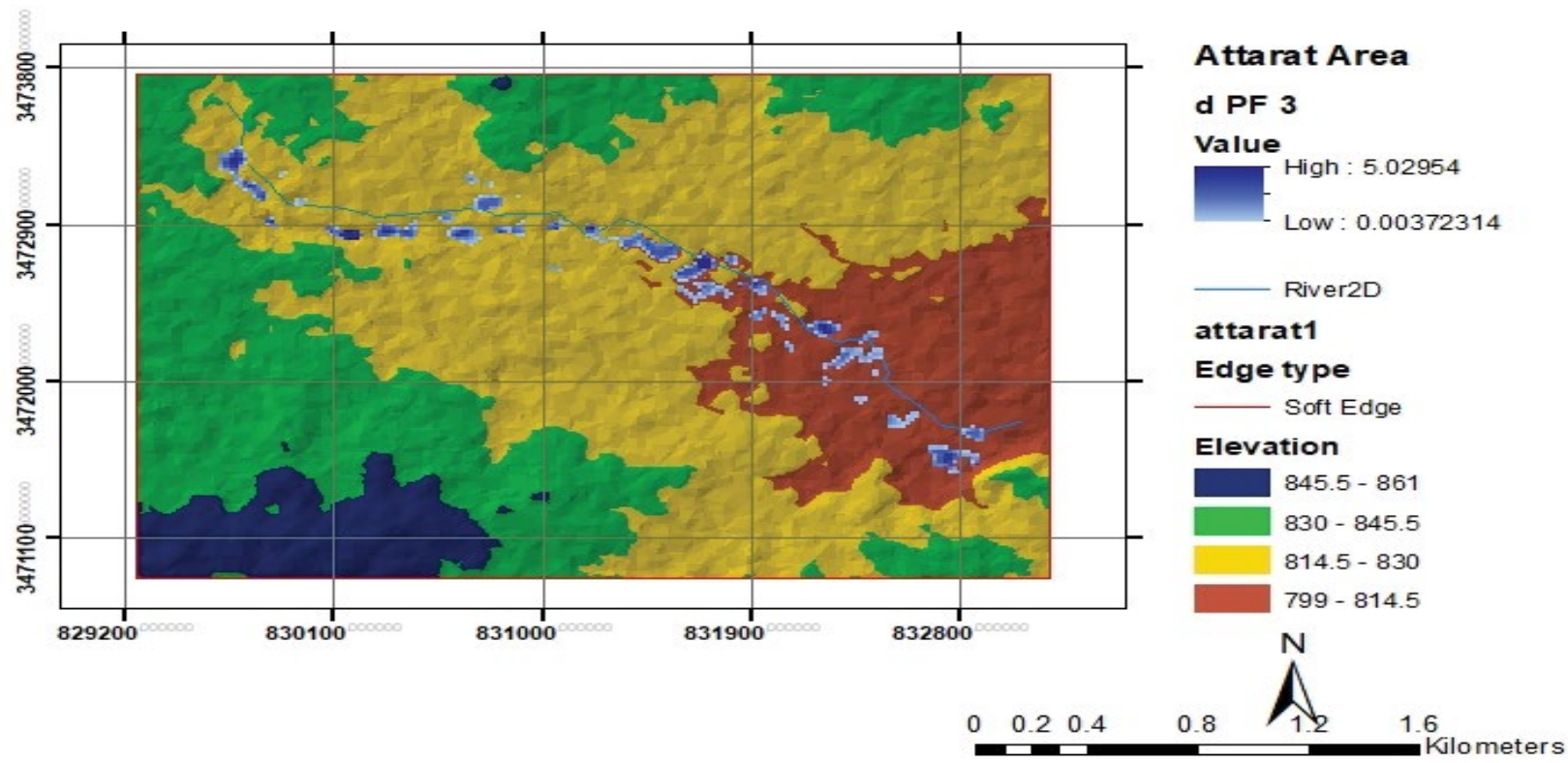

Figure 16: Floodplains for 100 years flow rate on the project area.

\begin{tabular}{|c|c|c|}
\hline Return period (years) & Runoff discharge (m) & Runoff volume (MCM) \\
\hline 2 & 0.84 & 0.592 \\
\hline 5 & 4.65 & 1.555 \\
\hline 10 & 8.63 & \\
\hline 25 & 13.98 & \\
\hline 50 & 18.71 & \\
\hline 100 & 28.283 & \\
\hline 200 & 28.73 & 3.976 \\
\hline
\end{tabular}

Table 1: Annual runoff discharge and runoff volume with different return periods for project area.

depth increases by $8.7 \%$ (i.e., from 1.42 to $1.6 \mathrm{~m}$ ). The analysis suggests that the model is working properly. As the roughness parameter was increased, decreases in average total velocity and Froude Number; and increases in hydraulic depth and water surface elevation occurred.

\section{Conclusion}

The purpose of this study was to map the floodplains of the Attarat Um Al-Ghudran Oil Shale Concession area using ArcGIS and other Hydraulic models. The analyzed data were incorporated into the various software programs to produce the desired floodplains. It was found from the analysis that there are many land parcels that could potentially be inundated by water in the event of large flows in the major river wadi in the study area. The results from this study provide useful information for mining activities that will take place during the extraction of oil shale to be aware of which land parcels may be affected if a flood were to occur. Knowing this information beforehand will allow the mining managers to take the appropriate precautions during times of flooding.

\section{References}

1. Kalyanapu AJ, Burian SJ, McPherson TN (2009) Effect of land use-based surface roughness on hydrologic model output. JOSH-ASHU 9: 51-71.

2. Golshan M, Jahanshahi A, Afzali A (2016) Flood hazard zoning using HECRAS in GIS environment and impact of manning roughness coefficient changes on flood zones in Semi-arid climate. Desert 21: 24-34.

3. Kvočka D, Falconer RA, Bray M (2015) Appropriate model use for predicting elevations and inundation extent for extreme flood events. Nat Hazards 79 1791-1808.
4. Opolot E (2013) Application of remote sensing and geographical information systems in flood management: A review. RJASET 6: 1884-1894.

5. Abu-Allaban M, El-Naqa A, Jaber M, Hammouri N (2014) Water scarcity impact of climate change in semi-arid regions: A case study in Mujib basin, Jordan. Arab J Geosci 8: 951-959.

6. Patel DP, Ramirez JA, Srivastava PK, Bray M, Han D (2017) Assessment of flood inundation mapping of Surat city by coupled 1D/2D hydrodynamic modeling: A case application of the new HEC-RAS 5. Nat Hazards 89: 93-130.

7. Şen Z, Khiyami HA, Al-Harthy SG, Al-Ammawi FA, Al-Balkhi A (2013) Flash flood inundation map preparation for wadis in arid regions. Arab J Geosci 6 : 3563-3572.

8. Elkhrachy I (2017) Assessment and management flash flood in najran wady using GIS and remote sensing. J Indian Soc Remote 46: 297-308.

9. Ghanbarpour MR, Salimi S, Solaimani K, Ahmadi MZ (2008) Floodplain mapping using hydraulic simulation model in GIS. J Appl Sci 8: 660-665.

10. US Army Corps of Engineers (2016) HEC-RAS River Analysis System, Hydraulic Reference Manual. Hydrologic engineering center report CPD-69, Davis, California, USA.

11. Hameed LK, Ali ST (2013) Estimating of manning's roughness coefficient for hilla river through calibration using HEC-RAS Model, Jordan J Civ Eng 44-53.

12. Ali ABM (2018) Flood inundation modeling and hazard mapping under uncertainties in the Sungai Johor Basin, Malaysia. (1st edn) London, CRC Press, UK: pp 178.

13. Sarhadi A, Soltani S, Modarres R (2012) Probabilistic flood inundation mapping of ungauged rivers: Linking GIS techniques and frequency analysis. J Hydrol 458-459: 68-86

14. AARC (Al-Urdun Al-jaded Research Center) (2001) The state of environment in Jordan, Annual Report. 
Citation: El-Naqa A, Jaber M (2018) Floodplain Analysis using ArcGIS, HEC-GeoRAS and HEC-RAS in Attarat Um Al-Ghudran Oil Shale Concession Area, Jordan. J Civil Environ Eng 8: 323. doi: 10.4172/2165-784X.1000323

15. US Army Corps of Engineers (2011) HEC-GeoRAS- GIS tools for support of HEC-RAS using ArcGIS, user's manual, Institute for water resources, Hydrologic engineering center report CPD-83, Davis, California, USA.

16. Horritt M, Bates PD (2002) Evaluation of $1 D$ and 2D numerical models for predicting river flood inundation. J Hydrol 268: 87-99.
17. Pappenberger F, Beven K, Horritt M, Blazkova S (2005) Uncertainty in the calibration of effective roughness parameters in HEC-RAS using inundation and downstream level observations. J Hydrol 302: 46-69. 